\title{
The secondary alcohol and aglycone metabolites of doxorubicin alter metabolism of human erythrocytes
}

F. Misiti ${ }^{1}$, B. Giardina ${ }^{1,2}$, A. Mordente ${ }^{1}$ and M.E. Clementi ${ }^{2}$
${ }^{1}$ Istituto di Biochimica e Biochimica Clinica, Facoltà di Medicina e Chirurgia, Università Cattolica del Sacro Cuore, Rome, Italy

${ }^{2}$ CNR, Istituto di Chimica del Riconoscimento Molecolare, Rome, Italy

\section{Correspondence \\ F. Misiti \\ Istituto di Biochimica e Biochimica \\ Clinica \\ Facoltà di Medicina e Chirurgia \\ Università Cattolica del Sacro Cuore \\ L.go F. Vito, No. 1 \\ 00168 Rome \\ Italy \\ Fax: +39-6-305-3598 \\ E-mail: f.misiti@uniserv.ccr.rm.cnr.it}

$\ldots \ldots \ldots \ldots \ldots \ldots$

Received June 2, 2003

Accepted September 23, 2003

\begin{abstract}
Anthracyclines, a class of antitumor drugs widely used for the treatment of solid and hematological malignancies, cause a cumulative dose-dependent cardiac toxicity whose biochemical basis is unclear. Recent studies of the role of the metabolites of anthracyclines, i.e., the alcohol metabolite doxorubicinol and aglycone metabolites, have suggested new hypotheses about the mechanisms of anthracycline cardiotoxicity. In the present study, human red blood cells were used as a cell model. Exposure $\left(1 \mathrm{~h}\right.$ at $\left.37^{\circ} \mathrm{C}\right)$ of intact human red blood cells to doxorubicinol $(40 \mu \mathrm{M})$ and to aglycone derivatives of doxorubicin $(40 \mu \mathrm{M})$ induced, compared with untreated red cells: i) a $\sim 2$-fold stimulation of the pentose phosphate pathway (PPP) and ii) a marked inhibition of the red cell antioxidant enzymes, glutathione peroxidase $(\sim 20 \%)$ and superoxide dismutase $(\sim 60 \%)$. In contrast to doxorubicinderived metabolites, doxorubicin itself induced a slighter PPP stimulation $(\sim 35 \%)$ and this metabolic event was not associated with any alteration in glutathione reductase, glutathione peroxidase, catalase or superoxide dismutase activity. Furthermore, the interaction of hemoglobin with doxorubicin and its metabolites induced a significant increase $(22 \%)$ in oxygen affinity compared with hemoglobin incubated without drugs. On the basis of the results obtained in the present study, a new hypothesis, involving doxorubicinol and aglycone metabolites, has been proposed to clarify the mechanisms responsible for the doxorubicin-induced red blood cell toxicity.
\end{abstract}

\section{Introduction}

Doxorubicin (DOX), an anthracycline drug widely used for the treatment of solid and hematological malignancies (1), causes cumulative dose-dependent cardiac toxicity characterized by irreversible dilated cardiomyopathy and congestive heart failure (2).
Key words

- Anthracyclines

- Doxorubicinol

- Doxorubicin

- Aglycone metabolite

- Pentose phosphate pathway

- $\left[{ }^{13} \mathrm{C}\right]-\mathrm{NMR}$ spectroscopy

- Hemoglobin 
of DOX-induced toxicity have implicated DOX metabolites other than semiquinone free radicals. Recently, it has been demonstrated that in human cardiac cytosol, DOX is primarily converted to a secondary alcohol metabolite, i.e., doxorubicinol (DOXol) and/or to a broad panel of aglycones (see Figure 1) by an NADP(H)-dependent mechanism (6). In vivo and in vitro studies have demonstrated that DOXol may be involved in several mechanisms of toxicity in heart tissue, which include inhibition of the $\mathrm{Ca}^{2+}$ / $\mathrm{Mg}^{2+}$ ATPase of sarcoplasmic reticulum, the F0-F1 proton pump of mitochondria and the $\mathrm{Na}^{+}-\mathrm{K}^{+}$ATPase and $\mathrm{Na}^{+}-\mathrm{Ca}^{2+}$ exchanger of sarcolemma $(7,8)$. Toxic effects on a number of mitochondrial functions $(9,10)$ have been reported for the aglycone derivatives of DOX.

Moreover, in vitro and in vivo studies

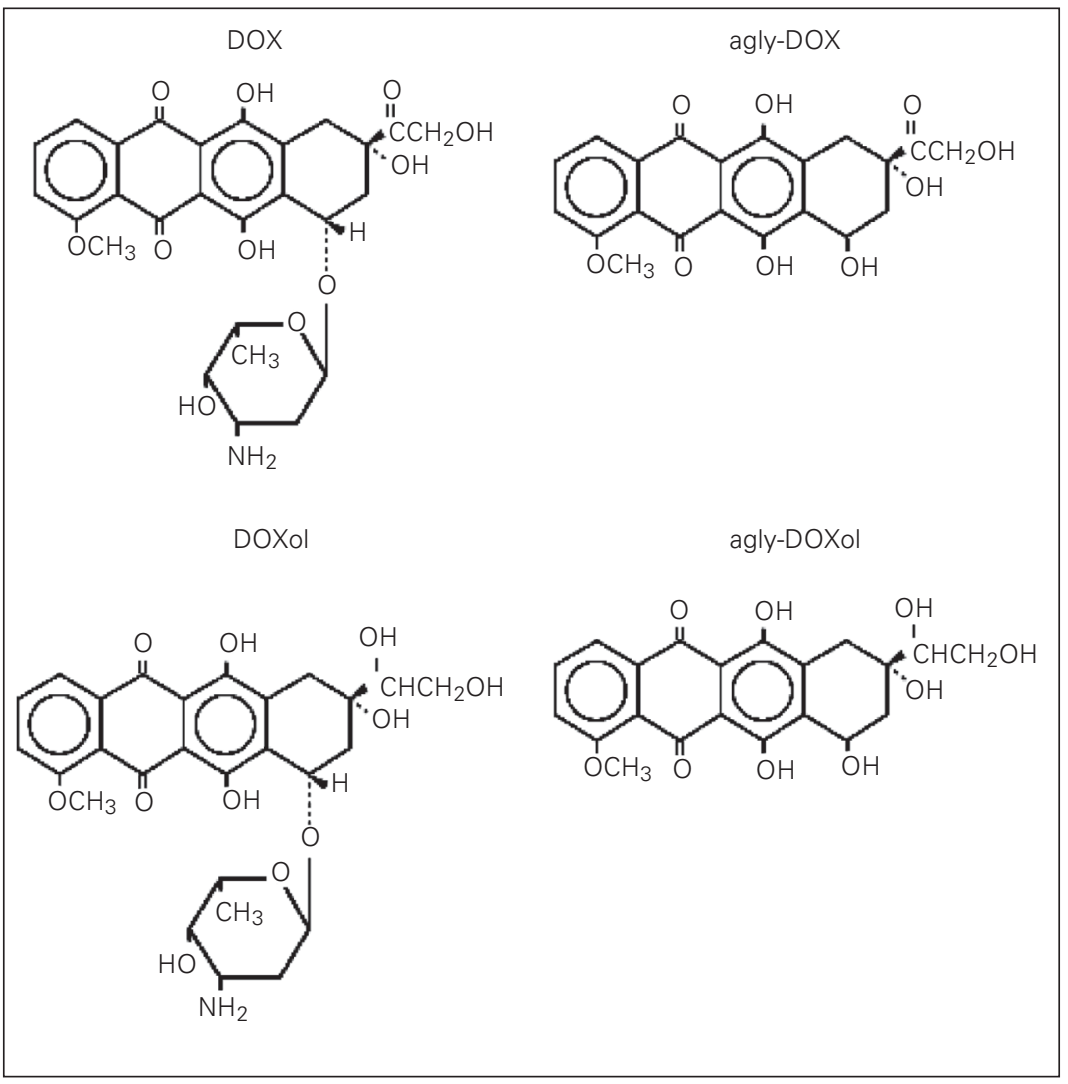

Figure 1. Chemical structures of doxorubicin (DOX), doxorubicinol (DOXol), aglycone-DOX (agly-DOX) and aglycone-DOXol (agly-DOXol). have shown that several parameters indicative of red blood cell function and integrity might be negatively affected by anthracycline drugs. In fact, changes in membrane ionic permeability (11), alteration of sodium transporters (12), inhibition of inositol lipid metabolism (13), increase in lipid peroxidation $(14,15)$, and alterations of membrane structure (16) have been reported. However, although several studies on the effects of anthracyclines on red blood cells have been performed, none of them were focused on the effects of the anthracycline metabolites other than semiquinone free radicals. Earlier reports have identified secondary alcohol and aglycone metabolites of DOX in human plasma as the major metabolites following intravenous administration of this drug $(17,18)$. Thus, it seemed appropriate to investigate the interaction of DOX metabolites with intact red blood cells and the consequent effects on their energy metabolism. A complete understanding of the functional alterations induced in human red blood cells not only by DOX but also by its main metabolites might lead to the development of new therapeutic uses of this drug.

\section{Material and Methods}

\section{Chemicals}

$\left[2-{ }^{13} \mathrm{C}\right]-$ Glucose was purchased from Cambridge Isotopes Laboratories (Andover, MA, USA). DOX hydrochloride and DOXol were obtained by Pharmacia \& Upjohn (Erlangen, Germany) and were dissolved in distilled water. The derived aglycones were prepared by heating the parent compounds at $100^{\circ} \mathrm{C}$ for $30 \mathrm{~min}$ in the presence of $2 \mathrm{~N}$ acetic acid and extracting the cleavage products with chloroform (19) and were dissolved in dimethyl sulfoxide (DMSO). Purity was checked by $\left[{ }^{1} \mathrm{H}\right]-\mathrm{NMR}$ (data not shown). All other reagents were of the highest grade available and were obtained from Sigma (St. Louis, MO, USA). 


\section{Preparation of red blood cells}

Heparinized fresh human blood was obtained from consenting informed healthy donors and processed immediately. Plasma was separated by centrifugation at $2500 \mathrm{~g}$ for $5 \mathrm{~min}$. Erythrocytes were washed four times with HEPES buffer ( $25 \mathrm{mM}$ Hepes, $1 \mathrm{mM}$ $\mathrm{NaH}_{2} \mathrm{PO}_{4}, 110 \mathrm{mM} \mathrm{NaCl}, 5 \mathrm{mM} \mathrm{KCl}$, and 2 $\mathrm{mM} \mathrm{MgCl} 2$ ), $\mathrm{pH} 7.4$, and $290 \pm 5 \mathrm{mOsm} / \mathrm{kg}$, measured with an Osmostat OM-6020 apparatus (Daiichikagakuco Ltd., Kyoto, Japan). The buffy coat together with part of the upper erythrocyte layer was removed and discarded after each washing step. After the washing procedure, the packed cells were gently resuspended with the HEPES buffer to obtain a $50 \%(\mathrm{v} / \mathrm{v})$ hematocrit. Subsequently, they were divided into 5 aliquots: four were incubated with the drugs, i.e., DOX, DOXol, aglycone-DOX (agly-DOX) and aglycone-DOXol (agly-DOXol), and one was left untreated (control). The concentrations of the drugs were $40 \mu \mathrm{M}$. After $1 \mathrm{~h}$ at $37^{\circ} \mathrm{C}$ in the dark, cell suspensions were washed twice with HEPES washing buffer ( $2500 \mathrm{~g}$ for $3 \mathrm{~min}$ at $4^{\circ} \mathrm{C}$ ) and used for the metabolic determinations. At the end of incubation, hemolysis was determined by measuring spectrophotometrically (Cary 3E, Varian, Palo Alto, CA, USA) the hemoglobin $(\mathrm{Hb})$ concentration in the supernatant solutions obtained by centrifugation at 2500 $g$ for $5 \mathrm{~min}$ at $4^{\circ} \mathrm{C}$. Methemoglobin (MetHb) levels were determined spectrophotometrically in lysed cells according to the method of Zijlstra et al. (20).

\section{Determination of the pentose phosphate pathway}

The pentose phosphate pathway (PPP) was determined by $\left[{ }^{13} \mathrm{C}\right]$-NMR spectroscopy performed on lysates of cells incubated with $\left[2-{ }^{13} \mathrm{C}\right]$-glucose. The following procedure was used to perform $\left[{ }^{13} \mathrm{C}\right]-\mathrm{NMR}$ measurements: both drug-treated and untreated in- tact red blood cells were suspended in HEPES buffer $(50 \%, \mathrm{v} / \mathrm{v})$ and the cell suspensions were incubated with $15 \mathrm{mM}\left[2-{ }^{13} \mathrm{C}\right]$-glucose for $6 \mathrm{~h}$ at $37^{\circ} \mathrm{C}$ in the dark, as reported by Misiti et al. (21). At the end of the incubation time, samples were checked for $\mathrm{pH}$ and $\mathrm{MetHb}$ concentration and then immediately mixed with an equal volume of cold $12 \%$ $\mathrm{HClO}_{4}$ solution (w/w). Denatured material was discarded after centrifugation (2000 $\mathrm{g}$, $10 \mathrm{~min}, 4^{\circ} \mathrm{C}$ ) and the acid supernatant was transferred to the NMR tube for $\left[{ }^{13} \mathrm{C}\right]-\mathrm{NMR}$ determinations. Experiments were performed using autoclaved plastic ware, glassware and buffers. Each step of sample preparation was performed in a sterile chamber to avoid sample contamination.

\section{$\left[{ }^{13} \mathrm{C}\right]-\mathrm{NMR}$ measurements}

$\left[{ }^{13} \mathrm{C}\right]-\mathrm{NMR}$ experiments were performed with a Gemini 300 Varian spectrometer, operating at $74.62 \mathrm{MHz}$ and $25^{\circ} \mathrm{C}$, using a 5$\mathrm{mm}$ diameter tube. A $45^{\circ}$ pulse, an acquisition time of 0.8-s and 1-s recovery between pulses were used. Spectra were broadband decoupled from protons and a line broadening of $1 \mathrm{~Hz}$ was applied before Fourier transformation. A sealed capillary containing a $50 \%{ }^{2} \mathrm{H}_{2} \mathrm{O} /$ methanol (v/v) solution was inserted into the NMR tube. Methanol resonance (49.9 ppm) was used as chemical shift reference. The PPP activity was assessed by measuring the ratio between the signals corresponding to lactate molecules labeled at C3 (methyl group) and at $\mathrm{C}-2$ (methyne group) generated from the metabolism of $\left[2-{ }^{13} \mathrm{C}\right]-$ glucose (22).

\section{Glutathione peroxidase, superoxide dismu- tase, glutathione reductase and catalase activities}

Antioxidant enzymes were measured at $37^{\circ} \mathrm{C}$ in hemolysates obtained from intact red blood cells after treatment with the drugs and from untreated intact cells. Glutathione 
peroxidase (GPx) was determined in a coupled assay in which the rate of tert-butyl hydroperoxide-dependent NADP $(\mathrm{H})$ oxidation at $340 \mathrm{~nm}$ was monitored by the method of Beutler (23). Superoxide dismutase (SOD) was assayed by monitoring the autoxidation of 6-hydroxydopamine at $490 \mathrm{~nm}$ by the method of Heikkila (24). Glutathione reductase (GR) was assayed spectrophotometrically by measuring the rate of $\mathrm{NADP}(\mathrm{H})$ oxidation at $340 \mathrm{~nm}$ (25). Catalase (CAT) activity was assayed using hydrogen peroxide as a substrate (23).

\section{Determination of oxygen equilibrium curves for hemoglobin}

Human $\mathrm{Hb}(\mathrm{HbA})$ was purified by lysing a packed preparation of washed human erythrocytes, followed by the addition of 2 volumes of cold hypotonic buffer. The stroma was removed by centrifugation at $12,000 \mathrm{~g}$ for $30 \mathrm{~min}$ and $\mathrm{HbA}$ purity was checked by isoelectrofocusing in $8 \mathrm{M}$ urea. Purity was always higher than $97 \%$. Organic and inorganic phosphates (i.e., stripped $\mathrm{Hb}$ ) were removed by passing the hemolysate first through a Sephadex G-25 column, equili-

Figure 2. DOX, DOXol, agly-DOX and agly-DOXol stimulate the pentose phosphate pathway (PPP) in human red blood cells. Human red blood cells were incubated for $1 \mathrm{~h}$ at $37^{\circ} \mathrm{C}$ in the presence and absence of $40 \mu \mathrm{M}$ DOX, $40 \mu \mathrm{M}$ DOXol, $40 \mu \mathrm{M}$ aglyDOX and $40 \mu \mathrm{M}$ agly-DOXol. After drug treatment, intact red blood cells were washed and incubated with $\left[2-{ }^{13} \mathrm{C}\right]$-glucose at $37^{\circ} \mathrm{C}$ for $6 \mathrm{~h}$. The PPP activity was assessed by measuring the ratio between the signals corresponding to lactate molecules

labeled at C-3 (methyl group) and at C-2 (methyne group) generated from the metabolism of $\left[2-{ }^{13} \mathrm{C}\right]$-glucose. Data are reported as percent of controls (no drugs, control cells $=100 \pm$ $5 \%, N=12$ ) and as means \pm SEM of the number of observations in separate experiments indicated in parentheses. The absolute value of PPP flux in the absence of any drug was $2.70 \pm 0.15 \mathrm{nmol} \mathrm{min}^{-1} \mathrm{ml}^{-1} \mathrm{RBC}(\mathrm{N}=12)$. The statistical significance of the effect of DOX, DOXol, agly-DOX and agly-DOXol treatment was determined by the paired Student $t$-test $\left({ }^{*} P<0.05 ;{ }^{*} P<0.01\right)$. For abbreviations, see legend to Figure 1. brated with $10 \mathrm{mM}$ Tris buffer, $\mathrm{pH} 8.0$, containing $0.1 \mathrm{M} \mathrm{NaCl}$, and then through a column of mixed-bed ion-exchange resin (BioRad AG 501X8, Hercules, CA, USA).

Oxygen binding isotherms were determined by the tonometric method (26) at a protein concentration of $5 \mathrm{mg} / \mathrm{ml}$. The study of the functional properties was performed in $0.1 \mathrm{M}$ HEPES buffer plus $100 \mathrm{mM} \mathrm{NaCl}$ and $10 \mathrm{mM}$ 2,3-diphosphoglyceric acid at $\mathrm{pH} 7.4$ and $37^{\circ} \mathrm{C}$. The drugs were used at 10 $\mu \mathrm{M}$ concentration. The formation of MetHb after each measurement was less than $5 \%$.

Titration of the sulfhydryl groups in $\mathrm{Hb}$ samples was performed according to the method of Boyer (27).

\section{Statistical analysis}

The significance of differences between the control and experimental groups was determined by the two-tailed Student $t$-test.

\section{Results}

Effect of the drugs on the metabolic pathways of red blood cells

When human erythrocytes were incubated for $1 \mathrm{~h}$ in the dark at $37^{\circ} \mathrm{C}$ in HEPES buffer in the presence or absence of $40 \mu \mathrm{M}$ DOX, $40 \mu \mathrm{M}$ DOXol, $40 \mu \mathrm{M}$ agly-DOX and 40 $\mu \mathrm{M}$ agly-DOXol, a higher PPP glucose flux was observed in the drug-treated red blood cells compared to control cells. In particular, as shown in Figure 2, DOX caused a 35\% PPP flux increase, whereas DOXol, aglyDOX and agly-DOXol caused a 60, 45 and $110 \%$ increase in PPP flux, respectively, compared to control. No changes of PPP flux were observed (data not shown) when red blood cells were incubated with DMSO for $1 \mathrm{~h}$ at $37^{\circ} \mathrm{C}$ in the dark, rouling out the possibility that DMSO itself might be responsible for the observed metabolic modifications. 
Effect of the drugs on red blood cell enzymes

To test the possibility that the alteration of erythrocyte metabolism following exposure to DOX, DOXol, agly-DOX and agly-DOXol might be linked to variation in GPx, SOD, GR or CAT activity, we performed an analysis of the activity of these enzymes in hemolysates. Figure 3 reports the effects of DOX, DOXol, agly-DOX and agly-DOXol on intracellular GPx activity. As can be seen, all DOX metabolites tested decreased GPx activity. In the presence of DOXol, agly-DOX and agly-DOXol, the inhibition of GPx activity was 19, 17 and $23 \%$, respectively, of that observed in control cells. In contrast, in intact red blood cells exposed to DOX, GPx activity was unaltered. Although we employed a conventional GPx assay system that used GR as a coupling enzyme, DOX, DOXol, agly-DOX and aglyDOXol did not affect the assay system (see Figure 3). Figure 4 shows the effects of DOX, DOXol, agly-DOX and agly-DOXol on intracellular SOD. SOD activity showed significant differences between controls and drugtreated red blood cells. In erythrocytes exposed to DOXol, agly-DOXol and agly-DOX, the inhibition of SOD activity was $60 \%$ of control. Contrary to DOX-derived metabolites, DOX itself had no significant effects on SOD activity. Figure 4 reports the effects of DOX, DOXol, agly-DOXol and agly-DOX on intracellular CAT. As can be seen, CAT activity was not significantly affected after $1 \mathrm{~h}$ of incubation with DOX, DOXol or its corresponding aglycone metabolites. These results are consistent with the suggestion that DOX and its metabolites may have different targets within the red blood cell.

\section{Oxygen equilibrium measurements}

Table 1 reports the change in $\mathrm{P}_{50}$ for $\mathrm{Hb}$ induced by DOX, DOXol, agly-DOX and agly$\mathrm{DOXol}$ at $\mathrm{pH} 7.4$ and $37^{\circ} \mathrm{C}$. It is evident that the presence of the drugs caused a $22 \%$ increase in oxygen affinity compared to control.
This suggests that DOX and its main metabolites may interact with $\mathrm{Hb}$ modifying its binding to oxygen, and consequently causing reduced tissue oxygenation. To test the possibility that alteration of $\mathrm{Hb}$ oxygen binding properties following exposure to DOX, DOXol, agly-DOX and agly-DOXol might be linked to the oxidation of thiol groups, we titrated the $3-93$ cysteines of $\mathrm{HbA}$ treated with the drugs using $\rho$-hydroxymercuribenzoate (PMB) (data not shown). The results obtained demonstrated that, in contrast to untreated $\mathrm{HbA}$, in samples incubated with DOX, DOXol

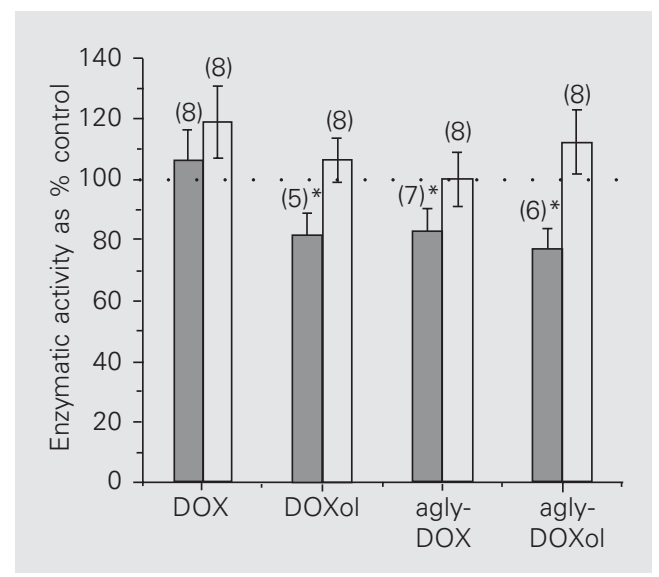

Figure 3. Effect of DOX, DOXol, agly-DOX and agly-DOXol on glutathione peroxidase (closed columns) and glutathione reductase (open columns) activity of human red blood cells. Human red blood cells were incubated for $1 \mathrm{~h}$ at $37^{\circ} \mathrm{C}$ in the presence and absence of $40 \mu \mathrm{M}$ DOX, 40 $\mu \mathrm{M}$ DOXol, $40 \mu \mathrm{M}$ agly-DOX and $40 \mu \mathrm{M}$ agly-DOXol, before hemolysis and enzymatic activity determinations as described in Material and Methods. Data are reported as percent of control activity (no drugs, control cells = $100 \pm 7 \%, N=6)$ and as means \pm SEM of the number of observations in separate experiments indicated in parentheses. The statistical significance of the effect of DOX, DOXol, agly-DOX and agly-DOXol treatment was determined by the paired Student $t$-test $\left({ }^{*} P<0.05\right)$. For abbreviations, see legend to Figure 1.

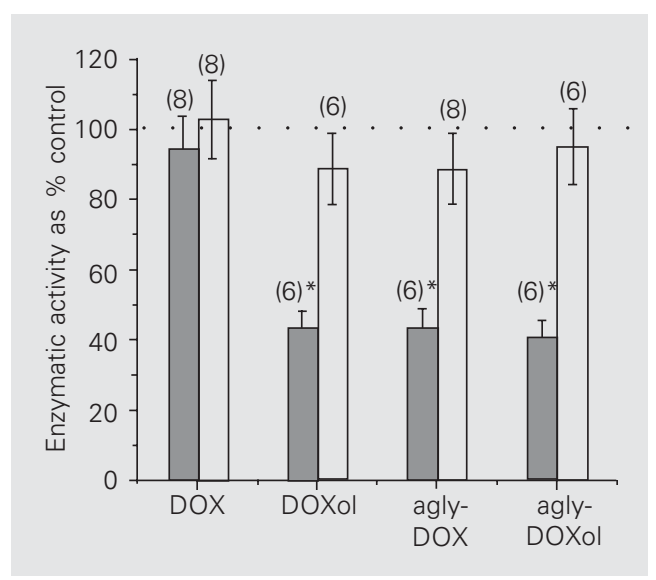

Figure 4. Effect of DOX, DOXol, agly-DOX and agly-DOXol on superoxide dismutase (closed columns) and catalase (open columns) activity of human red blood cells. Human red blood cells were incubated for $1 \mathrm{~h}$ at $37^{\circ} \mathrm{C}$ in the presence and absence of $40 \mu \mathrm{M}$ DOX, $40 \mu \mathrm{M}$ DOXol, $40 \mu \mathrm{M}$ agly-DOX and 40 $\mu \mathrm{M}$ agly-DOXol, before hemolysis and enzymatic activity determinations as described in Material and Methods. Data are reported as percent of control activity (no drugs, control cells = $100 \pm 10 \%, N=8$ ) and as means \pm SEM of the number of observations in separate experiments indicated in parentheses. The statistical significance of the effect of DOX, DOXol, agly-DOX and agly-DOXol treatment was determined by the paired Student $t$-test $\left({ }^{*} P<0.01\right)$. For abbreviations, see legend to Figure 1. 
and aglycones the - $\mathrm{SH}$ groups were not titratable, demonstrating a specific modification of this amino acid group by the drugs.

\section{Effects of drugs on Pmethemoglobin levels and hemolysis degree}

MetHb levels determined in intact red cells after treatment with anthracycline drugs and their metabolites were $6.3 \pm 4.3$, and the values for control cells were $5.6 \pm 6.0 \%, \mathrm{~N}=$ $6, \mathrm{P}=0.3$. MetHb levels did not change significantly even during $\left[2-{ }^{13} \mathrm{C}\right]$-glucose incubation $\left(6 \mathrm{~h}\right.$ at $\left.37^{\circ} \mathrm{C}\right)$. Percent hemolysis was always less than $2 \%$.

\section{Discussion}

The present study clearly demonstrates that not only DOX but also its main metabolites, i.e., the secondary alcohol DOXol and aglycone derivatives of DOX, dramatically affect the red blood cell energy metabolism, stimulating the PPP. These results are in agreement with previous studies that reported a dose-dependent activation of PPP in intact human erythrocytes after exposure to adriamycin and daunomycin exposure (28). Henderson et al. (28) proposed that DOX could

Table 1. Oxygen affinity of hemoglobin A in the absence and in the presence of doxorubicin (DOX), doxorubicinol (DOXol), aglycone-DOX (agly-DOX) and aglycone-DOXol (agly-DOXol).

\begin{tabular}{ll} 
Samples & $P_{50}$ \\
\hline $\mathrm{HbA}$ (control) & 23.0 \\
$\mathrm{HbA}+10 \mu \mathrm{M}$ DOX & $18.3^{*}$ \\
$\mathrm{HbA}+10 \mu \mathrm{M}$ DOXol & $18.2^{*}$ \\
$\mathrm{HbA}+10 \mu \mathrm{M}$ agly-DOX & $18.0^{*}$ \\
$\mathrm{HbA}+10 \mu \mathrm{M}$ agly-DOXol & $17.9^{*}$
\end{tabular}

Hemoglobin $\mathrm{A}(\mathrm{HbA})$ was incubated in $0.1 \mathrm{M}$ HEPES buffer, $0.1 \mathrm{M} \mathrm{NaCl}$ in the presence of 10 $\mathrm{mM} 2$,3-diphosphoglyceric acid at $\mathrm{pH} 7.4$ and $37^{\circ} \mathrm{C}$. The average SEM was $\pm 8 \%$ for $P_{50}$ values $(N=6)$. Data $\left(P_{50}\right)$ are reported in $\mathrm{mmHg}$. The statistical significance of the effect of DOX, DOXol, aglyDOX and agly-DOXol treatment was determined by the paired Student $t$-test ( ${ }^{*} P<0.05$ ). undergo cyclic oxidation-reduction within the red blood cell acting as a mediator of electron transfer from $\mathrm{NADP}(\mathrm{H})$ via semiquinone to oxyhemoglobin. Thus, the direct oxidation of $\mathrm{NADP}(\mathrm{H})$ by DOX could account for the larger portion of the PPP stimulation that we observed in intact red blood cells following DOX exposure. Therefore, the cited investigators proposed that the reactive oxygen species generated during the oxidation-reduction cycle of anthracyclines might oxidize intracellular glutathione and provide further PPP stimulation. Bates and Winterbourn (29) proposed that $\mathrm{O}_{2}^{-\bullet}$ and adriamycin semiquinone may be generated directly by reaction of adriamycin with oxyhemoglobin. However, although many in $v i$ tro studies devoted to the understanding of the biochemistry have emphasized the toxic effects of anthracyclines within the red blood cells, the molecular basis of these effects is not fully understood. Alternative mechanisms of DOX-induced toxicity have implicated DOX metabolites other than semiquinone free radicals. This is the case for DOXol, a hydroxy metabolite formed upon a two-electron reduction of the $\mathrm{C}-13$ carbonyl group in the side chain of DOX $(7,8,30)$ and for the aglycone metabolites $(9,10)$. Thus, in the present study, we used red blood cells as a cell model in order to acquire more information on the biological activity of DOXol, agly-DOX and agly-DOXol. It should also be noted that, although the concentrations of the drugs used in this study would not be achievable in the blood stream in normal human usage, in many earlier in vitro studies concerning the effects of anthracyclines or other drugs on red blood cell, the drugs were used at similar or higher concentrations $(13,16,28,29,31)$. Here, we show that both DOXol and the aglycone derivatives of DOX increased the PPP flux in human red blood cells. It is important to remark that DOXol as well as its corresponding aglycone metabolite were at least 1.8 times more potent than the parent compound in the stimulation of 
the PPP glucose flux. Recent studies carried out to identify the mechanisms responsible for the anthracycline-induced cardiotoxicity have demonstrated that DOXol might indeed be more potent than DOX in causing metabolic dysfunction $(7,8)$.

Due to the high levels of $\mathrm{Hb}$ within the red blood cells, it is possible that, under our experimental conditions, the interaction of some fractions of DOX and its metabolites with $\mathrm{Hb}$ may represent another important metabolic event occurring within the cell after drug exposure. Thus, we determined the $\mathrm{O}_{2}$ affinity of $\mathrm{Hb}$ treated with DOX and its metabolites in order to assess whether the interaction of $\mathrm{Hb}$ with the drugs may modify its oxygen binding properties. Under physiological conditions, we demonstrated an increase in the $\mathrm{O}_{2}$ affinity of drug-treated $\mathrm{Hb}$ compared to free-drug $\mathrm{Hb}$. This finding, plus the impossibility to titrate the - $\mathrm{SH}$ groups in drug-treated $\mathrm{Hb}$, is probably due to the chemical modification exerted by anthracycline drugs on the cysteine residues of $\mathrm{HbA}$. In this regard, it is known that the oxygen affinity of $\mathrm{HbA}$ is higher than normal when cysteines B-93 are chemically modified (32).

This result raises the new hypothesis of interplay between anthracyclines and $\mathrm{Hb}$ in addition to the recent suggestion regarding the existence of two binding sites for DOX on $\mathrm{Hb}(33,34)$. However, because the $\mathrm{O}_{2}$ affinity of $\mathrm{Hb}$ is a crucial factor in determining $\mathrm{O}_{2}$ delivery in the blood, in cancer patients treated with DOX a higher $\mathrm{O}_{2}$ affinity of blood might favor pulmonary $\mathrm{O}_{2}$ loading but impair $\mathrm{O}_{2}$ release to tissues. Although further study is required to clarify this point, we suggest that this finding might be relevant to the understanding of the mechanisms of toxicity induced by anthracyclines.

Previous studies have demonstrated that the toxic effects of DOX are believed to be mediated by free radicals (3-5). Thus, in an attempt to better clarify the mechanisms underlying the PPP stimulation and the increased $\mathrm{O}_{2}$ affinity of $\mathrm{Hb}$ observed in red blood cell following exposure to DOX and DOX metabolites, we assessed the activities of different red cell antioxidative enzymes, including GPx, SOD, CAT and GR. Our data showed that DOX treatment had no significant effects on the red cell GPx, SOD, CAT and GR enzymes, in agreement with in vitro reports that red cell enzymes of the reduction systems are not inactivated by DOX (35). In contrast to DOX, DOXol and the aglycone derivatives of DOX only inhibited the red cell GPx and SOD enzymes. In this respect, we suggest that a large accumulation of oxygen reactive species within the red blood cells after treatment with DOXol and aglycone derivatives of DOX might represent an inevitable consequence of impairment of the red cell GPx and SOD enzymes induced by DOX metabolites. Thus, the oxidation of sulfhydryl groups, induced by the oxygen reactive species accumulated within the red blood cell, may account for the larger portion of the PPP stimulation and for the increased $\mathrm{O}_{2}$ affinity of $\mathrm{Hb}$ that we observed in intact red blood cells following DOXol and aglycone metabolites exposure.

Furthermore, the present data allow us to suggest that differences in PPP activity which exist among cell types may lead to variability in the sensitivity of cells to toxicity induced by DOX metabolites. This is consistent with earlier findings showing that multidrug resistant cells have an elevated PPP activity $(36,37)$.

On the basis of the present findings, we hypothesize that in cancer patients treated with anthracyclines, as plasma levels of DOXol and aglycone metabolites increase during prolonged exposure to the drug, an impairment of the activity of the red blood cell antioxidant enzymes may progressively alter the redox status of the cell, inducing important alterations in the red blood cell functions. Furthermore, the results of this study support the hypothesis that DOX metabolites other than semiquinone free radicals might play an important role in the mechanisms responsible for DOX-induced cell toxicity. 


\section{References}

1. Singal PK \& lliskovic N (1998). Doxorubicin-induced cardiomyopathy. New England Journal of Medicine, 339: 900-905.

2. Lefrak EA, Pitha J, Rosenheim S \& Gottlieb JA (1973). A clinical pathological analysis of adriamycin cardiotoxicity. Cancer, 32: 302314.

3. Olson RD \& Mushlin PS (1990). Doxorubicin cardiotoxicity: analysis of prevailing hypotheses. FASEB Journal, 4: 3076-3086.

4. Powis $G$ (1989). Free radical formation by antitumor quinones. Free Radical Biology and Medicine, 6: 63-101.

5. Singal PK, Deally CMR \& Weinberg LE (1987). Subcellular effects of adryamicin in the heart: a concise review. Journal of Molecular and Cellular Cardiology, 19: 817-828.

6. Licata S, Saponiero A, Mordente A \& Minotti G (2000). Doxorubicin metabolism and toxicity in human myocardium: Role of cytoplasmic deglycosylation and carbonyl reduction. Chemical Research in Toxicology, 13: 414-420.

7. Boucek Jr RJ, Olson RD, Brenner DE, Ogumbumni ME, Inui M \& Flescher $S$ (1987). The major metabolite of doxorubicin is a potent inhibitor of membrane associated ion pumps: a correlative study of cardiac muscle with isolated membrane fractions. Journal of Biological Chemistry, 262: 15851-15856.

8. Olson RD, Mushlin PS, Brenner DE, Fleischer S, Cusack BJ, Chang BK \& Boucek Jr RJ (1988). Doxorubicin cardiotoxicity may be caused by its metabolite, doxorubicinol. Proceedings of the National Academy of Sciences, USA, 85: 3585-3589.

9. Sokolove PM, Kester MB \& Haynes J (1993). Interaction of adriamycin aglycones with isolated mitochondria. Effect of selenium deficiency. Biochemical Pharmacology, 46: 691-697.

10. Sokolove PM \& Shinaberry RG (1988). Na+-independent release of $\mathrm{Ca}^{2+}$ from rat heart mitochondria. Induction by adriamycin aglycone. Biochemical Pharmacology, 37: 803-812.

11. Harper JR, Orringer EP \& Parker JC (1979). Adriamycin inhibits $\mathrm{Ca}^{2+}$ permeability and Ca-dependent $\mathrm{K}^{+}$movements in red blood cells. Research Communications in Chemical Pathology and Pharmacology, 26: 277-284.

12. Borg A, Gallice PM, Kovacic HN, Nicoara AE, Favre RG \& Crevat AD (1996). Impairment of sodium pump and $\mathrm{Na}^{+} / \mathrm{H}^{+}$antiport in erythrocytes isolated from cancer patients. Cancer Research, 56: 511-514.

13. Thompson MG, Chahwala SB \& Hickman JA (1987). Inhibition of human erythrocyte inositol lipid metabolism by adriamycin. Cancer Research, 47: 2799-2803.

14. Miura T, Muraoka S \& Ogiso T (1993). Adriamycin-induced lipid peroxidation of erythrocyte membranes in the presence of ferritin and the inhibitory effect of ceruplasmin. Biological and Pharmaceutical Bulletin, 16: 664-667.

15. DeAtley SM, Aksenov MY, Aksenova MV, Carney JM \& Butterfield DA (1998). Adriamycin induces protein oxidation in erythrocyte membrane. Pharmacology and Toxicology, 83: 62-68.

16. Suwalsky $M$, Hernandez $P$, Villena $F$, Aguilar $F$ \& Sotomayor $C P$ (1999). The anticancer drug adriamycin interacts with the human erythrocyte membrane. Zeithschrift für Naturforschung. Section C, 54c: $271-277$.

17. Andersen A, Holte H \& Slordal L (1999). Pharmacokinetics and metabolism of doxorubicin after short-term infusions in lymphoma patients. Cancer Chemotherapy and Pharmacology, 44: 422-426.

18. Lachatre F, Marquet P, Ragot S, Gaulier JM, Cardot P \& Dupuy JL (2000). Simultaneous determination of four anthracyclines and three metabolites in human serum by liquid chromatography-electrospray mass spectrometry. Journal of Chromatography. B, Biomedical Applications, 738: 281-291.

19. Takanashi S \& Bachur NR (1976). Adriamycin metabolism in man. Evidence from urinary metabolism. Drug Metabolism and Disposition, 4: 79-87.

20. Zijlstra WG, Buursma A \& Meeuwsen-van der Roest WP (1991). Absorption spectra of human fetal and adult oxyhemoglobin, deoxyhemoglobin, carboxyhemoglobin, and methemoglobin. Clinical Chemistry, 37: 1633-1638.

21. Misiti F, Meucci E, Zuppi C, Vincenzoni F, Giardina B, Castagnola M \& Messana I (2002). O $\mathrm{O}_{2}$-dependent stimulation of the pentose phosphate pathway by S-nitrosocysteine in human erythrocytes. Biochemical and Biophysical Research Communications, 294: 829834.

22. Messana I, Ferroni F, Misiti F, Girelli G, Pupella M, Castagnola M, Zappacosta B \& Giardina B (2000). Blood bank conditions and RBCs: the progressive loss of metabolic modulation. Transfusion, 40: 353360.

23. Beutler E (1975) Red cell metabolism. In: Beutler E (Editor), A Manual of Biochemical Methods. 2nd edn. Grune \& Stratton, New York, 71-73.

24. Heikkila RE (1985). Autoxidation of 6-hydroxydopamine. In: Greenwald RA (Editor), Handbook of Methods for Oxygen Radicals Research. CRC Press, Boca Raton, FL, USA, 233-235.

25. Carlberg I \& Mannervik B (1985). Glutathione reductase. Methods in Enzymology, 113: 484-490.

26. Giardina B \& Amiconi G (1981). Measurement of binding of gaseous and non gaseous ligands to hemoglobins by conventional spectrophotometric procedures. Methods in Enzymology, 76: 417-427.

27. Boyer PD (1954). Spectrophotometric study of the reaction of protein sulfhydryl groups with organic mercurials. Journal of the American Chemical Society, 76: 4331-4337.

28. Henderson CA, Metz EN, Balcerzak SP \& Sagone Jr AL (1978). Adriamycin and daunomycin generate reactive oxygen compounds in erythrocytes. Blood, 52: 878-885.

29. Bates DA \& Winterbourn CC (1982). Reaction of adriamycin with haemoglobin. Superoxide dismutase indirectly inhibits reactions of the adriamycin semiquinone. Biochemical Journal, 203: 155-160.

30. Minotti G, Recalcati S, Mordente A, Liberi G, Calafiore AM, Mancuso C, Preziosi P \& Cairo G (1998). The secondary alcohol metabolite of doxorubicin irreversibly inactivates aconitase/iron regulatory protein-1 in cytosolic fractions from human myocardium. FASEB Journal, 12: 541-552.

31. McMillan DC, Jensen CB \& Jollow DJ (1998). Role of lipid peroxidation in dapsone-induced hemolytic anemia. Journal of Pharmacology and Experimental Therapeutics, 287: 868-876.

32. Antonini E, Condo SG, Giardina B, loppolo C \& Bertollini A (1982). The effect of $\mathrm{pH}$ and D-glycerate 2,3-bisphosphate on the $\mathrm{O}_{2}$ equilibrium of normal and $\mathrm{SH}$ (beta 93)-modified human hemoglobin. European Journal of Biochemistry, 121: 325-328.

33. Ramanathan-Girish S \& Boroujerdi M (2001). Contradistinction between doxorubicin and epirubicin: in vitro interaction with blood components. Journal of Pharmacy and Pharmacology, 53: 15-21.

34. Vaidyanathan S \& Boroujerdi M (2000). Interaction of dexrazoxane with red blood cells and hemoglobin alters pharmacokinetics of doxorubicin. Cancer Chemotherapy and Pharmacology, 46: 93-100.

35. Shinohara K \& Tanaka KR (1980). The effects of adriamycin (doxorubicin $\mathrm{HCl}$ ) on human red blood cells. Hemoglobin, 4: 735-745. 
36. Miccadei S, Fanciulli M, Bruno T, Paggi MG \& Floridi A (1996). Energy metabolism of adryamicin-sensitive and resistant Ehrlich ascites tumor cells. Oncology Research, 8: 27-35.

37. Ferretti A, Chen LL, Di Vito M, Barca S, Tombesi M, Cianfriglia M,
Bozzi A, Strom R \& Podo F (1993). Pentose phosphate pathway alterations in multi drug resistant leukemic T-cells: 31P NMR and enzymatic studies. Anticancer Research, 13: 867-872. 